\title{
Assessment of Sleep Quality in Healthcare Workers as Part of the COVID-19 Outbreak
}

\author{
COVID-19 Salgını Kapsamında Sağlık Çalışanlarında Uyku Kalitesinin Değerlendirilmesi
}

\author{
(1) Tuba Akınc1 ${ }^{1}$, (1) Hatice Melek Başar ${ }^{2}$ \\ ${ }^{1}$ Beylikduzu State Hospital, Clinic of Neurology, Istanbul, Turkey \\ 2Beylikduzu State Hospital, Clinic of Psychiatry, Istanbul, Turkey
}

\begin{abstract}
Objective: We aimed to evaluate the sleep quality and affceting factors of the healthcare professionals working in our hospital during the coronavirus disease-2019 (COVID-19) pandemic.

Materials and Methods: One hundred fifty-two healthcare professionals, 95 females and 57 males working during the COVID-19 pandemic, were included in our study. In the study, the factors affecting sleep quality were statistically evaluated by using the patients' demographic features, the Pittsburgh Sleep Quality Index (PSQI), Fatigue Severity Scale, and Beck Anxiety and Beck Depression Scale.

Results: According to the PSQI results, the participants of our study were divided into two groups as PSQI $\geq 5(\mathrm{n}=109,71.7 \%)$ and PSQI $<5$ ( $\mathrm{n}=43,28.1 \%)$. In the group with poor sleep quality (PSQI $\geq 5)$, there were more females ( $\mathrm{p}=0.003)$, the average age was younger $(\mathrm{p}=0.013)$, and the rate of anxiety and depression was higher $(\mathrm{p}<0.001$ and $\mathrm{p}<0.001)$.

Conclusion: According to the results of our study, during the COVID-19 pandemic, the quality of sleep of the healthcare staff was significantly impaired. The health of health professionals is also important in this long process. Practices for improving the quality of sleep of healthcare staff will contribute to the long-term struggle by strengthening the immune system in the fight of health workers against the virus.
\end{abstract}

Keywords: Sleep quality, healthcare staff, COVID-19 pandemic

Öz

Amaç: Hastanemizde koronavirüs hastalı̆̆1-2019 (COVID-19) pandemisi sırasında çalışan să̆lık personelinin uyku kalitesi ve buna etki eden faktörlerin değerlendirilmesi amaçlanmıştır.

Gereç ve Yöntem: Çalışmamıza COVID-19 pandemisi süresince çalışan 95 kadın, 57 erkek olmak üzere 152 sağlık çalışanı dahil edildi. Çalışmada, hastaların demografik özellikleri, Pitssburgh Uyku Kalitesi İndeksi (PUKI), Yorgunluk Şiddet Ölçeği (YŞÖ), Beck Anksiyete Ölçeği ve Beck Depresyon Ölçeği kullanılarak uyku kalitesine etki eden faktörler istatistiksel olarak değerlendirilmiştir.

Bulgular: Çalışmamıza katılanlar PUKİ sonucuna göre PUKİ $\geq 5 n=109(\% 71,7)$ ve PUKİ $<5 n=43(\% 28,1)$ olarak 2 gruba ayrıldı. Uyku kalitesi bozuk olan grupta (PUKI $\geq 5)$ kadın cinsiyetin ön planda olduğu ( $\mathrm{p}=0,003$ ), yaş ortalamasının daha düşük olduğu ( $\mathrm{p}=0,013$ ), anksiyete ve depresyon oranının daha yüksek olduğu ( $\mathrm{p}=0,001$ ve $\mathrm{p}=0,001)$ olduğu gözlendi. Çalışmamızda fiziksel yorgunluğu değerlendirmek amacıyla yapılan YŞÖ’de gruplar arasında fark gözlenmedi.

Sonuç: Çalışmamızın sonuçlarına göre COVID-19 pandemisi süresince sağlık personelinin uyku kalitesinin belirgin düzeyde bozulduğu saptanmıstır. Sağlık çalışanlarının să̆ $\breve{l ̆ g}_{1}$ da bu uzun süreçte önemlidir. Sağlık personelinin uyku kalitesinin artışına yönelik uygulamalar sağlık çalışanlarının virüsle mücadelesinde immün sistemi güçlendirerek uzun soluklu mücadeleye katkı să̆layabilir.

Anahtar Kelimeler: Uyku kalitesi, sağlık personeli, COVID-19 pandemisi

Address for Correspondence/Yazışma Adresi: Tuba Akıncı MD, Beylikduzu State Hospital, Clinic of Neurology, Istanbul, Turkey Phone: +902128562740 E-mail: tuubakinci@gmail.com ORCID: orcid.org/0000-0001-8521-7003

Received/Gelis Tarihi: 30.08.2020 Accepted/Kabul Tarihi: 20.02.2021

${ }^{\circ}$ Copyright 2021 by Turkish Neurological Society

Turkish Journal of Neurology published by Galenos Publishing House. 


\section{Introduction}

The new coronavirus disease is a viral infection with high pathogenicity and contagiousness caused by severe acute respiratory syndrome (SARS)-coronavirus-2. It was first defined in Wuhan, China, in December 2019, and spread all over the world (1). Pneumonia caused by the new type of coronavirus was named coronavirus disease-2019 (COVID-19) by the World Health Organization on February $11^{\text {th }}, 2020$. It has affected approximately 4 million people worldwide (2).

The risk of transmission with COVID-19 increases due to the close contact of healthcare professionals with patients affected by COVID-19. More than 16,000 healthcare workers in Italy were infected with COVID-19 $(3,4)$. According to the recently announced data in our country, around 7.000 healthcare workers were reported to be infected (5). Healthcare workers are concerned about both their health and their family's health during the pandemic. Factors such as being infected by the virus, concern for infecting others, loneliness, and increased self-expectation put the physical and psychological health of healthcare personnel at risk. The use of airtight personal protective equipment for hours every day has increased the workload. The need for frequent contact with patients in isolation units has exhausted healthcare professionals both physically and psychologically (6). The lack of a vaccine with proven efficiency against COVID-19 and the presence of only symptomatical treatment increase the stress. In the previous pandemic of SARS, it was reported that the sleep cycles of healthcare personnel returned to normal only two weeks after the crisis ended $(7,8)$. Work-related stress, sleep deprivation, shift work, and fatigue often cause sleep disturbances and poor sleep quality (PSQI) in healthcare workers (9). In this study, we aimed to evaluate the sleep quality and fatigue of healthcare workers during the COVID-19 pandemic in our hospital and to determine the factors that affected them.

\section{Materials and Methods}

This study was conducted in accordance with the Declaration of Helsinki. All participants signed consent forms. The Ethics Committee of Istanbul Health Sciences University, Kanuni Sultan Suleyman Training and Research Hospital approved the study (KAEK/2020.06.60). Healthcare personnel working in the emergency department, inpatient ward, and intensive care units, where patients with COVID-19 were treated, between April and May 2020 were included in our study. People who volunteered for the study and could cooperate with the survey were included in the study. A semi-structured sociodemographic data form was administered by the interviewer, in which socio-demographic characteristics and questions about COVID-19 were asked, and the Pittsburgh Sleep Quality Index (PSQI), Fatigue Severity Scale (FSS), Beck Anxiety Inventory (BAI) and Beck Depression Scales (BDI) and scoring systems were used in the study.

Socio-demographic Data Form: Individuals were asked questions about age, sex, marital status, occupation, educational status, chronic disease history, children, working hours, working years, COVID-19 test results, and the COVID-19 pandemic (Table 1).

\section{The Pittsburgh Sleep Quality Index}

To determine the sleep quality of individuals in the last month, the PSQI, which is a self-consistent and repeatable, reliable test, was used ( $\alpha$ : 0.77). The PSQI contains 19 questions that enable an individual to evaluate the quality and quantity of sleep, presence and severity of sleep disorders. It is a questionnaire consisting of seven items evaluating subjective sleep quality, sleep latency, sleep duration, sleep efficiency, sleep disturbance, use of sleeping medication, and impairment in daytime work (10). A total PSQI score below 5 indicates "good sleep quality”. The PSQI questionnaire was adapted to the Turkish language by Agargun et al. (11) (Figure 1).

\section{The Fatigue Severity Scale}

The FSS was developed by Krupp et al. (12) in 1989, and its validity and reliability study was conducted in 2007 by Armutlu et al. (13). A 9-item FSS was created by selecting fatigue characteristics. The score for each question ranges between 1-7. The total score is obtained as the sum or average of all answers (Figure 2).

\section{Beck Anxiety Inventory}

It is a self-assessment scale developed by Beck et al. (14) to determine the frequency of anxiety symptoms experienced by individuals. The scale consists of 21 items. It is a Likert-type scale with a score ranging from 0 to 3 for each question. A reliability and validity study in Turkey was performed by Ulusoy et al. (15) in 1998 (Figure 3).

\section{Beck Depression Inventory}

The BDI was created to measure the physical, emotional and cognitive symptoms seen in depression. It is a self-assessment scale consisting of 21 items. The score for each question ranges from 0 to 3 . The total score of the scale is between 0-63. Scores of 21 or above indicate the presence of moderate or severe depression (16). The Turkish validity and reliability study of this scale was conducted by Hisli (17) (Figure 4).

\section{Statistical Analysis}

After the data of the research were collected, they were evaluated on a computer by the researcher. The Statistical Package for the Social Sciences-PC Version 21.0 (SPSS) package program was used for the statistical analysis of the data. Mean \pm standard deviation and percentage values were calculated for all variables. The chi-square test was used to compare the difference between categorical variables for analysis. The differences between the two groups in terms of numerical variables were determined using the Mann-Whitney U test, which was a non-parametric test. The results of the research were evaluated by accepting the value of $\mathrm{p} \leq 0.05$ at the 0.95 confidence interval as significant.

\section{Results}

In our study, 152 healthcare professionals working in our hospital during the COVID-19 pandemic were included. The average age of the participants was $35.8 \pm 9.29$ (range, 19-59) years. Of the participants, 95 (62.5\%) were women and $57(37.5 \%)$ were men. When classified according to occupational groups, there were $40(26.5 \%)$ physicians, $72(47 \%)$ nurses, and $40(26.5 \%)$ other healthcare professionals. Of the participants, $118(78.3 \%)$ were undergraduates, $18(11.8 \%)$ had an associate degree, and 14 (9.2\%) had high school or lower education level. 


\section{Pittsburgh Sleep Quality Index (PSQI)}

Name:

Date:

Instructions: The following questions relate to your usual sleep habits during the past month only. Your answers should indicate the most accurate reply for the majority of days and nights in the past month. Please answer all questions.

1. During the past month, what time have you usually gone to bed at night?

2. During the past month, how long (in minutes) has it usually taken you to fall asleep each night?

3. During the past month, what time have you usually gotten up in the morning?

4. During the past month, how many hours of actual sleep did you get at night? (This may be different than the number of hours you spent in bed.)

\begin{tabular}{|c|c|c|c|c|}
\hline $\begin{array}{l}\text { 5. During the past month, how often have you had } \\
\text { trouble sleeping because you... }\end{array}$ & \begin{tabular}{c|c} 
ad & Not during \\
the past \\
month
\end{tabular} & $\begin{array}{l}\text { Less than } \\
\text { once a } \\
\text { week }\end{array}$ & $\begin{array}{l}\text { Once or } \\
\text { twice a } \\
\text { week }\end{array}$ & $\begin{array}{l}\text { Three or more } \\
\text { times a week }\end{array}$ \\
\hline \multicolumn{5}{|l|}{ a. Cannot get to sleep within 30 minutes } \\
\hline \multicolumn{5}{|l|}{$\begin{array}{l}\text { b. Wake up in the middle of the night or early } \\
\text { morning }\end{array}$} \\
\hline \multicolumn{5}{|l|}{ c. Have to get up to use the bathroom } \\
\hline \multicolumn{5}{|l|}{ d. Cannot breathe comfortably } \\
\hline \multicolumn{5}{|l|}{ e. Cough or snore loudly } \\
\hline \multicolumn{5}{|l|}{ f. Feel too cold } \\
\hline \multicolumn{5}{|l|}{ g. Feel too hot } \\
\hline \multicolumn{5}{|l|}{ h. Have bad dreams } \\
\hline \multicolumn{5}{|l|}{ i. Have pain } \\
\hline \multicolumn{5}{|l|}{ j. Other reason(s), please describe: } \\
\hline \multicolumn{5}{|l|}{$\begin{array}{l}\text { 6. During the past month, how often have you } \\
\text { taken medicine to help you sleep (prescribed or } \\
\text { "over the counter")? }\end{array}$} \\
\hline \multicolumn{5}{|l|}{$\begin{array}{l}\text { 7. During the past month, how often have you had } \\
\text { trouble staying awake while driving, eating meals, } \\
\text { or engaging in social activity? }\end{array}$} \\
\hline & $\begin{array}{l}\text { No } \\
\text { problem } \\
\text { at all }\end{array}$ & $\begin{array}{l}\text { Only a } \\
\text { very slight } \\
\text { problem }\end{array}$ & $\begin{array}{l}\text { Somewhat } \\
\text { of a } \\
\text { problem }\end{array}$ & $\begin{array}{l}\text { A very big } \\
\text { problem }\end{array}$ \\
\hline \multicolumn{5}{|l|}{$\begin{array}{l}\text { 8. During the past month, how much of a problem } \\
\text { has it been for you to keep up enough enthusiasm } \\
\text { to get things done? }\end{array}$} \\
\hline & $\begin{array}{l}\text { Very } \\
\text { good }\end{array}$ & $\begin{array}{l}\text { Fairly } \\
\text { good }\end{array}$ & $\begin{array}{l}\text { Fairly } \\
\text { bad }\end{array}$ & $\begin{array}{l}\text { Very } \\
\text { bad }\end{array}$ \\
\hline \multicolumn{5}{|l|}{$\begin{array}{l}\text { 9. During the past month, how would you rate } \\
\text { your sleep quality overall? }\end{array}$} \\
\hline & $\begin{array}{l}\text { No bed } \\
\text { partner or } \\
\text { room mate }\end{array}$ & $\begin{array}{l}\text { Partner/room } \\
\text { mate in } \\
\text { other room }\end{array}$ & $\begin{array}{l}\text { Partner in } \\
\text { same room bu } \\
\text { not same bed }\end{array}$ & $\begin{array}{l}\text { Partner in } \\
\text { same bed }\end{array}$ \\
\hline \multicolumn{5}{|l|}{$\begin{array}{l}\text { 10. Do you have a bed partner or room } \\
\text { mate? }\end{array}$} \\
\hline & $\begin{array}{l}\text { Not during } \\
\text { the past } \\
\text { month }\end{array}$ & $\begin{array}{c}\text { Less than } \\
\text { once a week }\end{array}$ & $\begin{array}{l}\text { Once or twice } \\
\text { a week }\end{array}$ & $\begin{array}{l}\text { Three or } \\
\text { more times } \\
\text { a week }\end{array}$ \\
\hline \multicolumn{5}{|l|}{$\begin{array}{l}\text { If you have a room mate or bed partner, ask } \\
\text { him/her how often in the past month you have } \\
\text { had: }\end{array}$} \\
\hline \multicolumn{5}{|l|}{ a. Loud snoring } \\
\hline \multicolumn{5}{|l|}{ b. Long pauses between breaths while asleep } \\
\hline \multicolumn{5}{|l|}{ c. Legs twitching or jerking while you sleep } \\
\hline \multicolumn{5}{|l|}{ d. Episodes of disorientation or confusion } \\
\hline $\begin{array}{l}\text { e. Other restlessness while you sleep, please } \\
\text { describe: }\end{array}$ & & & & \\
\hline
\end{tabular}

Figure 1. Pittsburgh Sleep Quality Index 


\section{FATIGUE SEVERITY SCALE (FSS)}

Date

Name

Please circle the number between 1 and 7 which you feel best fits the following statements. This refers to your usual way of life within the last week. 1 indicates "strongly disagree" and 7 indicates "strongly agree."

\begin{tabular}{|c|c|c|c|c|c|c|c|}
\hline Read and circle a number. & & gly & agree & $\rightarrow$ & S & $\overline{g l}$ & \\
\hline $\begin{array}{l}\text { 1. My motivation is lower when I am } \\
\text { fatigued. }\end{array}$ & 1 & 2 & 3 & 4 & 5 & 6 & 7 \\
\hline 2. Exercise brings on my fatigue. & 1 & 2 & 3 & 4 & 5 & 6 & 7 \\
\hline 3. I am easily fatigued. & 1 & 2 & 3 & 4 & 5 & 6 & 7 \\
\hline $\begin{array}{l}\text { 4. Fatigue interferes with my physical } \\
\text { functioning. }\end{array}$ & 1 & 2 & 3 & 4 & 5 & 6 & 7 \\
\hline $\begin{array}{l}\text { 5. Fatigue causes frequent problems for } \\
\text { me. }\end{array}$ & 1 & 2 & 3 & 4 & 5 & 6 & 7 \\
\hline $\begin{array}{l}\text { 6. My fatigue prevents sustained physical } \\
\text { functioning. }\end{array}$ & 1 & 2 & 3 & 4 & 5 & 6 & 7 \\
\hline $\begin{array}{l}\text { 7. Fatigue interferes with carrying out } \\
\text { certain duties and responsibilities. }\end{array}$ & 1 & 2 & 3 & 4 & 5 & 6 & 7 \\
\hline $\begin{array}{l}\text { 8. Fatigue is among my most disabling } \\
\text { symptoms. }\end{array}$ & 1 & 2 & 3 & 4 & 5 & 6 & 7 \\
\hline $\begin{array}{l}\text { 9. Fatigue interferes with my work, family, } \\
\text { or social life. }\end{array}$ & 1 & 2 & 3 & 4 & 5 & 6 & 7 \\
\hline
\end{tabular}

\section{VISUAL ANALOGUE FATIGUE SCALE (VAFS)}

Please mark an " $X$ " on the number line which describes your global fatigue with 0 being worst and 10 being normal.

\begin{tabular}{|lllllllllllll}
\hline 0 & 1 & 2 & 3 & 4 & 5 & 6 & 7 & 8 & 9 & 10 \\
\hline
\end{tabular}

Figure 2. Fatigue Severity Scale 


\section{Beck Anxiety Inventory}

Below is a list of common symptoms of anxiety. Please carefully read each item in the list. Indicate how much you have been bothered by that symptom during the past month, including today, by circling the number in the corresponding space in the column next to each symptom.

\begin{tabular}{|c|c|c|c|c|}
\hline & Not at all & $\begin{array}{l}\text { Mildly, but it } \\
\text { didn't bother } \\
\text { me much }\end{array}$ & $\begin{array}{l}\text { Moderately - it } \\
\text { wasn't pleasant } \\
\text { at times }\end{array}$ & $\begin{array}{c}\text { Severely - it } \\
\text { bothered me } \\
\text { a lot }\end{array}$ \\
\hline Numbness or tingling & 0 & 1 & 2 & 3 \\
\hline Feeling hot & 0 & 1 & 2 & 3 \\
\hline Wobbliness in legs & 0 & 1 & 2 & 3 \\
\hline Unable to relax & 0 & 1 & 2 & 3 \\
\hline Fear of worst happening & 0 & 1 & 2 & 3 \\
\hline Dizzy or lightheaded & 0 & 1 & 2 & 3 \\
\hline Heart pounding / racing & 0 & 1 & 2 & 3 \\
\hline Unsteady & 0 & 1 & 2 & 3 \\
\hline Terrified or afraid & 0 & 1 & 2 & 3 \\
\hline Nervous & 0 & 1 & 2 & 3 \\
\hline Feeling of choking & 0 & 1 & 2 & 3 \\
\hline Hands trembling & 0 & 1 & 2 & 3 \\
\hline Shaky / unsteady & 0 & 1 & 2 & 3 \\
\hline Fear of losing control & 0 & 1 & 2 & 3 \\
\hline Difficulty in breathing & 0 & 1 & 2 & 3 \\
\hline Fear of dying & 0 & 1 & 2 & 3 \\
\hline Scared & 0 & 1 & 2 & 3 \\
\hline Indigestion & 0 & 1 & 2 & 3 \\
\hline Faint / lightheaded & 0 & 1 & 2 & 3 \\
\hline Face flushed & 0 & 1 & 2 & 3 \\
\hline Hot / cold sweats & 0 & 1 & 2 & 3 \\
\hline
\end{tabular}

Figure 3. Beck Anxiety Inventory 


\section{Beck's Depression Inventory}

This depression inventory can be self-scored. The scoring scale is at the end of the questionnaire.
1. 0 I do not feel sad
1 I feel sad
2 I am sad all the time and I can't snap out of it
3 I am so sad and unhappy that I can't stand it
2. 0 I am not particularly discouraged about the future
1 I feel discouraged about the future
2 I feel I have nothing to look forward to
3 I feel the future is hopeless and that things cannot improve

3. 0 I do not feel like a failure

1 I feel I have failed more than the average person

2 As I look back on my life, all I can see is a lot of failures

3 I feel I am a complete failure as a person

4. 0 I get as much satisfaction out of things as I used to

1 I don't enjoy things the way I used to

2 I don't get real satisfaction out of anything anymore

3 I am dissatisfied or bored with everything

5. 0 I don't feel particularly guilty

1 I feel guilty a good part of the time

2 I feel quite guilty most of the time

3 I feel guilty all of the time

6. 0 I don't feel I am being punished

1 I feel I may be punished

2 I expect to be punished

3 I feel I am being punished

7. 0 I don't feel disappointed in myself

$1 \quad$ I am disappointed in myself

2 I am disgusted with myself

3 I hate myself

8. 0 I don't feel I am any worse than anybody else

1 I am critical of myself for my weaknesses or mistakes

2 I blame myself all the time for my faults

3 I blame myself for everything bad that happens

9. 0 I don't have any thoughts of killing myself

1 I have thoughts of killing myself, but I would not carry them out

2 I would like to kill myself

3 I would kill myself if I had the chance

10. 0 I don't cry any more than usual

1 I cry more now than I used to

2 I cry all the time now

3 I used to be able to cry, but now I can't cry even though I want to

11. 0 I am no more irritated by things than I ever was

1 I am slightly more irritated now than usual

2 I am quite annoyed or irritated a good deal of the time

3 I feel irritated all the time
12. 0 I have not lost interest in other people

1 I am less interested in other people than I used to be

2 I have lost most of my interest in other people

3 I have lost all of my interest in other people

13. 0 I make decisions about as well as I ever could

1 I put off making decisions more than I used to

2 I have greater difficulty in making decisions more than I used to

3 I can't make decisions at all anymore

14. 0 I don't feel that I look any worse than I used to

1 I am worried that I am looking old or unattractive

2 I feel there are permanent changes in my appearance that make me look unattractive

3 I believe that I look ugly

15. 0 I can work about as well as before

1 It takes an extra effort to get started at doing something

2 I have to push myself very hard to do anything

3 I can't do any work at all

16. 0 I can sleep as well as usual

1 I don't sleep as well as I used to

2 I wake up 1-2 hours earlier than usual and find it hard to get back to sleep

3 I wake up several hours earlier than I used to and cannot get back to sleep.

17. 0 I don't get more tired than usual

1 I get tired more easily than I used to

2 I get tired from doing almost anything

3 I am too tired to do anything

18. 0 My appetite is no worse than usual

1 My appetite is not as good as it used to be

2 My appetite is much worse now

3 I have no appetite at all anymore

19. 0 I haven't lost much weight, if any, lately

1 I have lost more than five pounds

2 I have lost more than ten pounds

3 I have lost more than fifteen pounds

20. 0 I am no more worried about my health than usual

1 I am worried about physical problems like aches, pains, upset stomach, or constipation

2 I am very worried about physical problems and it's hard to think of much else

3 I am so worried about my physical problems that I cannot think of anything else

21. 0 I have not noticed any recent change in my interest in sex

1 I am less interested in sex than I used to be

2 I have almost no interest in sex

3 I have lost interest in sex completely

Figure 4. Beck Depression Scale 
Sleep quality was evaluated according to the total PSQI score. The sleep quality of those with a total PSQI score of $<5$ was considered good, and the sleep quality of those with a score of $\geq 5$ was considered poor. The participants were divided into two groups as PSQI $<5(\mathrm{n}=43,28.1 \%)$ and PSQI $\geq 5(\mathrm{n}=109,71.7 \%)$. Those with PSQI $<5$ were named as group 1 , and those with PSQI $\geq 5$ as group 2. The mean total PSQI value was $6.55 \pm 3.40$. The mean values of PSQI components were compared between the groups (Table 2).

In group 2, PSQI total score and subjective sleep quality, sleep latency, sleep duration, habitual sleep efficiency, sleep disorder, and daytime dysfunction component scores were significantly higher than subjects without sleep disorders $(p \leq 0.05)$. No significant difference was found in terms of the use of sleeping pills (Table 2).

The groups were compared in terms of age, sex, marital status, educational status, weekly working hours, and years of work, COVID-19 test result, childbearing status, and chronic disease status. It was shown that there were significantly more females in the group with poor sleep quality (group 2) ( $\mathrm{p}=0.003)$. It was observed that the average age was significantly older in those with good sleep quality (group 1) $(\mathrm{p}=0.013)$. No significant difference was found in terms of marital status, children, chronic disease history, working years and working hours. Again, there was no significant difference in terms of sleep quality between healthcare personnel (physicians and nurses) who directly intervened with patients and other healthcare personnel (e.g. secretary, laboratory, technician) who were not involved in treatment $(\mathrm{p}=0.272)$ (Table 3).
Groups were evaluated in terms of depression and anxiety using the BDI and the BAI.

In group 1, $37(86 \%)$ participants had no depression and six (14\%) had mild and moderate depression. In group 2, $56(51 \%)$ participants had no depression, $52(48 \%)$ had mild and moderate depression. Severe depression was found in one (1\%) participant. In group 1, 11 (26\%) participants had moderate and mild anxiety, and $32(74 \%)$ had no anxiety. Of the individuals in group 2, 61 $(56 \%)$ had mild-moderate anxiety, nine $(8 \%)$ had severe anxiety, and $39(36 \%)$ had no anxiety. It was observed that anxiety and depression rates were significantly higher in the group with poor sleep quality $(\mathrm{p}<0.001)$ (Table 4$)$.

When evaluated in terms of fatigue severity scale, no significant difference was observed between the groups $(\mathrm{p}=0.652)$ (Table 4).

Participants were asked questions about the COVID-19 pandemic. The percentages of the answers given to the questions in groups 1 and 2 were compared respectively: "I do not have a shortage of protective equipment $(62.8 \%-58.7 \%)$, I use protective equipment correctly $(95.3 \%-86.2 \%)$, I believe that protective equipment protects me adequately (74.4\%-67\%), I follow current publications during the pandemic (79\%-59.6\%), I think I have received sufficient training to prevent the transmission of COVID-19 disease (65.1\%-51.3\%), since I take care of patients with COVID-19, I am afraid that the disease will infect me (48\%$44 \%)$, I think we are successful as a health system in combating the pandemic (83\%-67.8\%)" (Graphic 1). No significant difference was observed between the two groups in terms of the questions, except for those who followed the current publications and

\section{Table 1. Survey questions on the COVID-19 pandemic}

*I have no shortage of protective equipment when caring for patients with COVID-19

*I use the protective equipment correctly

*I believe that the protective equipment protects me adequately

*I follow current publications during the pandemic

*I think I have received enough training to prevent the transmission of COVID-19

*Since I take care of patients with COVID-19, I am afraid that the disease will infect me

*I think we are successful as a health system in combating the pandemic

(1) (2) (3) (4) (5)

(1)(2)(3)(4)(5)

(1) (2) (3) (4) (5)

(1) (2) (3) (4) (5)

(1) (2) (3)(4) (5)

(1) (2) (3) (4) (5)

(1) (2) (3) (4) (5)

(1) Never/strongly disagree, (2)rarely/disagree, (3)occasionaly/partially agree, (4)mostly/agree, (5)always/totally agree.

COVID-19: Coronavirus disease-2019

Table 2. Comparison between groups in terms of Pittsburgh Sleep Quality Index total score and component scores

\begin{tabular}{|c|c|c|c|c|}
\hline & Total n $(\mathrm{n}=152)$ & PSQI $<5(n=43)$ & PSQI $\geq 5(n=109)$ & $\mathrm{p}$ \\
\hline PSQI-Total score & $6.55 \pm 3.40$ & $2.67 \pm 1.18$ & $8.03 \pm 2.73$ & $<0.001$ \\
\hline Subjective sleep quality & $1.39 \pm 0.74$ & $0.74 \pm 0.45$ & $1.65 \pm 0.67$ & $<0.001$ \\
\hline Sleep latency (delay) & $1.52 \pm 0.98$ & $0.67 \pm 0.69$ & $1.85 \pm 0.87$ & $<0.001$ \\
\hline Sleep duration & $0.79 \pm 0.99$ & $0.17 \pm 0.38$ & $1.03 \pm 1.05$ & $<0.001$ \\
\hline Habitual sleep efficiency & $0.22 \pm 0.57$ & $0.02 \pm 0.15$ & $0.29 \pm 0.65$ & 0.005 \\
\hline Sleeping disorder & $1.41 \pm 0.62$ & $0.90 \pm 0.37$ & $1.61 \pm 0.59$ & $<0.001$ \\
\hline Use of sleeping pills & $0.09 \pm 0.40$ & $0.00 \pm 0.00$ & $0.13 \pm 0.47$ & 0.074 \\
\hline Daytime dysfunction & $1.13 \pm 0.95$ & $0.17 \pm 0.38$ & $1.50 \pm 0.83$ & $<0.001$ \\
\hline
\end{tabular}


Table 3. Comparative evaluation of the groups according to their demographic characteristics

\section{Group $1($ PSQI $<5)(n=43) \quad$ Group $2(P S Q I \geq 5)(n=109) \quad$ p}

Demographic features

Sex

Male $\quad 23$

Female 20

Age

$39.13 \pm 9.27$

34

0.003

$34.6 \pm 9.29$

0.013

Marital status

Single

Married

$13 \quad 49$

30

60

0.950

Educational status

Licence

$32 \quad 86$

Associate degree $\quad 5 \quad 13$

$\begin{array}{lll}\text { High school or lower } & 4 & 10\end{array}$

\section{Occupation}

$\begin{array}{lll}\text { Physician } & 17 & 23\end{array}$

$\begin{array}{lll}\text { Nurse } & 13 & 59\end{array}$

Other medical staff

13 27

0.272

COVID-19 test

Negative 18

Positive

Not performed

$18 \quad 55$

$7 \quad 5$

18

0.053

Working hours (weekly)

Less than 45 hours 24

$\geq 45$ hours

$24 \quad 58$

Working years

$<10$ years $\quad 15$

$\geq 10$ years 28

53

$\begin{array}{ll}53 & 56\end{array}$

Chronic disease

$\begin{array}{lll}\text { Yes } & 9 & 24\end{array}$

No $\quad 34$

85

0.981

PSQI: Pittsburgh Sleep Quality Index, COVID-19: Coronavirus disease-2019

thought that they were successful as a health system in combating the pandemic, which was found to be significantly higher in the group with PSQI $<5$ ( $\mathrm{p}=0.020$ and $\mathrm{p}=0.019$, respectively) (Table 4).

\section{Discussion}

According to our study, it was observed that in the COVID-19 pandemic, a significant part $(71.7 \%)$ of the healthcare personnel working in the units related to this disease had deterioration in sleep quality. It was found in the group with poor sleep quality that female sex was prominent, that the average age was younger, that the rates of anxiety and depression were higher, that the rate of following current publications was less, and that the rate of thinking that they were successful as a health system in combating the pandemic was lower.

COVID-19 is a highly contagious disease. This virus particularly threatens healthcare workers. Healthcare workers struggle against the virus by working more intensively with personal protective equipment. However, when examining the relationship between the pandemic and healthcare workers, it is clear that other factors should be examined for the maintenance of the health system and

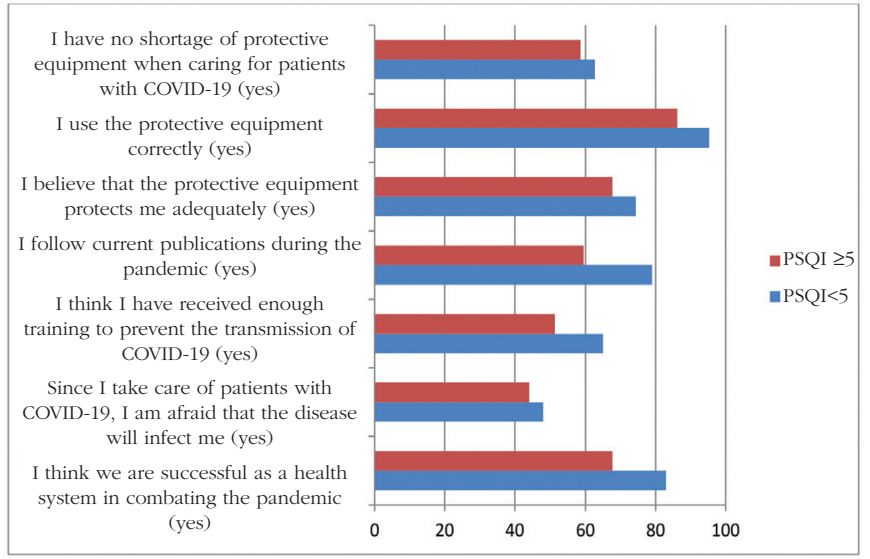

Graphic 1. Comparison of answers to questions about the COVID-19 pandemic between groups

PSQI: Pittsburgh Sleep Quality Index, FSS: Fatigue Severity Scale, COVID-19: Coronavirus disease-2019 
Table 4. Comparison of answers to questions on anxiety, depression, fatigue severity scale and COVID-19 pandemic

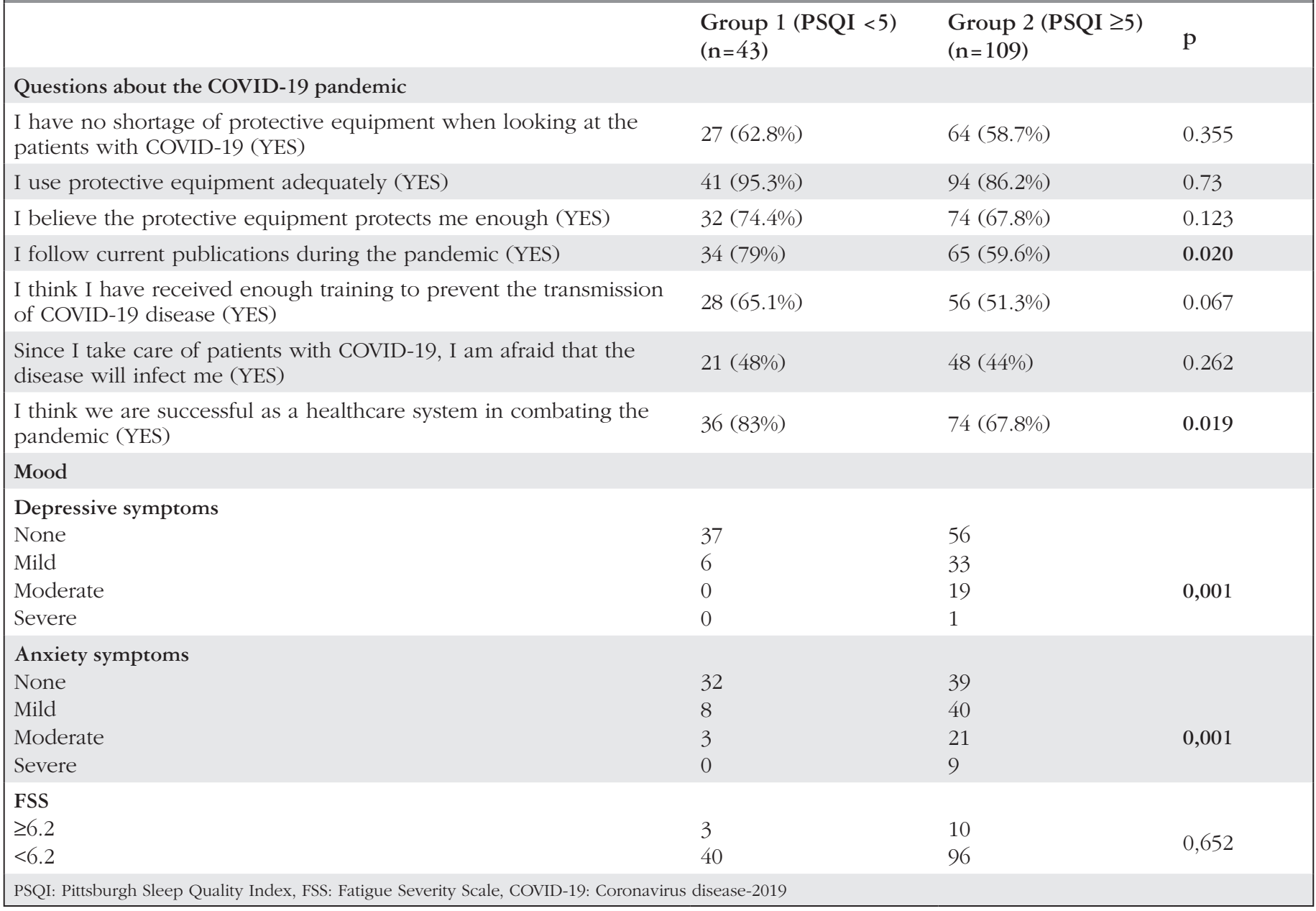

the health of healthcare professionals. The most important defense in COVID-19 infection, for which there is no vaccine and no obvious treatment, is a strong immune system. An indispensable element of a healthy immune system is quality sleep $(9,18,19)$. Therefore, sleep quality in healthcare workers was evaluated in our study. According to our study, a significant deterioration in sleep quality was observed in the COVID-19 pandemic in the healthcare personnel working in the units related to this disease. Experiences obtained in the previous SARS pandemic indicated that $34.2 \%$ of healthcare workers had insomnia in Hong Kong and $37 \%$ in Taiwan $(20,21)$. In a study conducted in Tehran, it was found that $43 \%$ of healthcare workers had sleep disorders (22). In a study conducted in China, the origin of the pandemic and the center of the pandemic for a long time, it was found that $64 \%$ of healthcare workers had sleep disorders (23). The results in our country were compatible with the literature, and it was reported that there was a deterioration in sleep quality in healthcare workers in many countries of the world.

The most important reason for the deterioration in sleep quality in healthcare professionals is their fight against the virus, for which there is no proven vaccine and which has very high contagiousness. As the COVID-19 pandemic spreads, millions of people are recommended to work from home due to social distance, but healthcare professionals continue to work at high risk in hospitals and clinics to minimize the risk of transmission. In China, it was shown that a total of 1716 healthcare workers were diagnosed as having COVID-19 and five died until February $11^{\text {th }}$, 2020 , with a case mortality rate of $0.3 \%$ (24). Reports from Italy indicated that $20 \%$ of healthcare workers were infected, while in Spain, healthcare workers infected with COVID-19 accounted for about $12 \%$ of all patients $(25,26)$. The stress factor is increasing as thousands of healthcare professionals become infected and some die. Previous studies have confirmed that stress is closely related to sleep quality (27). Increased stress can increase environmental alertness levels, which reduces sleep quality (28). Stress occurs in response to increased physical and psychological activation and causes sleep disturbance due to the activated hypopituitaryadrenal system (HPA) (29). The resulting sleep disturbances also lead to more activation in the HPA system, so a vicious cycle of insomnia and stress appears.

Isolation is one of the main treatment steps during the COVID-19 pandemic. In previous studies, it was stated that prolonged isolation led to negative behaviors (30). Healthcare personnel are also unfortunately affected by the isolation and quarantine processes due to the contamination effect on family members, friends, and colleagues. This emerges as a factor that 
increases psychological stress (31).

During the SARS pandemic in 2003, studies conducted in Beijing, Taiwan, Hong Kong, Singapore, and Canada showed that health personnel had post-traumatic stress disorder, anxiety or depression, which were affected by psychological conditions $(32,33,34,35,36)$. In our study, it was observed that anxiety and depressive symptoms were significantly higher in healthcare workers with impaired sleep quality $(\mathrm{p}<0.0001$ and $\mathrm{p}<0.0001$, respectively).

In our study, no significant difference was found between those with poor sleep quality and those without in terms of FSS, which was conducted to evaluate physical fatigue, and it was noted that psychological effects were more pronounced.

In a study conducted by Suzuki et al. (37) on 4.407 nurses in Japan in 2005, it was revealed that sleep quality impairment adversely affected the work efficiency of nurses. Factors such as sex and age can affect the prevalence of sleep disorders. Women are diagnosed as having insomnia almost twice as often as men. In our study, it was found that female healthcare professionals working in COVID-19 units had significantly impaired sleep quality $(\mathrm{p}=0.003)$.

In previous studies, the relationship between sleep disorder and education level was evaluated, and it was found that personnel with a low level of education reported insomnia more $(38,39)$. In our study, no significant difference was found between education levels and sleep quality. This can be explained by the low number of personnel who graduated from high school and lower school. In a study on SARS, it was stated that low education level was associated with fear of SARS (40). In our survey questions, it was noticed that people who were afraid of the transmission of COVID-19 had a lower education level, in line with the literature.

Factors related to insomnia during the COVID-19 pandemic include uncertainties such as not following the COVID-19 pandemic and current publications adequately and the feeling of insecurity about the health system during the COVID-19 pandemic.

In addition to stress, circadian rhythm disturbances in healthcare professionals can lead to insomnia symptoms. As it is known, some researchers have argued that because circadian rhythm disorder can disrupt immune system function, it may increase the susceptibility to infection $(18,19)$. Good sleep quality for healthcare professionals helps them work better to treat patients and maintains optimal immune function to prevent infection (41). Therefore, sleep quality is an important indicator of health.

\section{Study of Limitations}

The number of healthcare personnel evaluated was small because it was limited to healthcare personnel in a single center. Accordingly, it was thought that conducting similar multi-center studies that could represent all healthcare professionals would be beneficial.

\section{Conclusion}

One of the most important factors in ensuring the continuity of the health system in this long process is the health of health workers. Reducing stressor factors in healthcare professionals will reduce anxiety and depressive symptoms and improve sleep quality.

Few studies have been conducted on the physical and psychological effects of serious infectious disease outbreaks on healthcare professionals in situations of stress associated with increased workload and risk of infection. More studies on this population should be conducted to understand the causes of increased risk of transmission and high mortality in healthcare workers. Given that the pandemic will continue for weeks, research data are urgently needed to provide timely and supportive psychosocial interventions.

\section{Ethics}

Ethics Committee Approval: The Ethics Committee of Istanbul Health Sciences University, Kanuni Sultan Suleyman Training and Research Hospital approved the study (KAEK/2020.06.60).

Informed Consent: All participants signed consent forms. Peer-review: Externally peer-reviewed.

\section{Authorship Contributions}

Concept: T.A., Design: T.A., Data Collection or Processing: T.A., Analysis or Interpretation: T.A., H.M.B., Literature Search: T.A., H.M.B., Writing: T.A.

Conflict of Interest: No conflict of interest was declared by the authors.

Financial Disclosure: The authors declared that this study received no financial support.

\section{References}

1. Shereen MA, Khan S, Kazmi A, Bashir N, Siddique R. COVID-19 infection: Origin, trans-mission, and characteristics of human coronaviruses. J Adv Res 2020;24:91-98.

2. Organization WH. Laboratory testing for coronavirus disease 2019 (COVID-19) in sus-pected human cases: interim guidance. World Health Organization, 2 March 2020.

3. Belingheri M, Paladino ME, Riva MA. COVID-19: health prevention and control in nonhealthcare settings. Occup Med (Lond) 2020:20;70:82-83.

4. Belingheri M, Paladino ME, Riva MA. Beyond the assistance: additional exposure situations to COVID-19 for healthcare workers. J Hosp Infect 2020;105:353.

5. Fox TV Web Sayfası (2020), Son Erişim Tarihi: 11.06.2020. Erişim adresi: https://www.fox.com.tr/Fatih-Portakal-ile-FOX-Ana-Haber/ekstravideo/51523/Virus-gorulen-saglik-calisanlari

6. Centers for Disease Control and Prevention. Severe acute respiratory syndrome- Taiwan, 2003. MMWR Morb Mortal Wkly Rep 2003;52:461466.

7. Wu KK, Chan SK, Ma TM. Posttraumatic stress, anxiety, and depression in survivors of severe acute respiratory syndrome (SARS). J Trauma Stress 2005; 18:39-42.

8. Hawryluck L, Gold WL, Robinson S, et al. SARS control and psychological effects of Quarantine, Toronto, Canada. Emerg Infect Dis 2004;10:12061212.

9. Belingheri M, Pellegrini A, Facchetti R, et al. Self-reported prevalence of sleep disorders among medical and nursing students. Occup Med (Lond) 2020;70:127-130.

10. Buysse DJ, Reynolds CF 3rd, Monk TH, et al. Quantification of subjective sleep quality in healthy elderly men and women using the Pittsburgh Sleep Quality Index (PSQI). Sleep 1991;14:331-338.

11. Agargun MY, Kara H, Anlar O. The validity and reliability of the Pittsburgh Sleep Quality Index. Türk Psikiyatri Derg 1996;7:107-115.

12. Krupp LB, Alvarez LA, LaRocca NG, Scheinberg LC. Fatigue in multiple sclerosis, Arch Neurol 1988;45:435-437.

13. Armutlu K, Korkmaz NC, Keser I, et al. The validity and reliability of the fatigue severity scale in turkish multiple sclerosis patients. Int J Rehabil Res 2007;30:81-85.

14. Beck AT, Epstein N, Brown, Steer RA. An inventory for measuring clinical 
anxiety Psychometric properties. J Concult Clin Psychol 1988;56:893-897.

15. Ulusoy M, Şahin N, Erkmen H. Turkish version of the Beck Anxiety Inventory: Psychometric properties. J Cogn Psychother 1998;12:163-182.

16. Beck AT, World $\mathrm{CH}$, Mendelson $\mathrm{M}$, et al. An İnventory for measuring depression. Arch Gen Psychiatry 1961;4:561-571.

17. Hisli N. A study on the validity of the Beck Depression Inventory. Turk Psychol J 1988;6:118-123.

18. Cuesta M, Boudreau P, Dubeau-Laramée G, Cermakian N, Boivin DB. Simulated night shift disrupts circadian rhythms of immune functions in humans. J Immunol 2016;196:2466-2475.

19. Wirth MD, Andrew ME, Burchfiel CM, et al. Association of shiftwork and immune cells among police officers from the Buffalo. Cardio-Metabolic Occupational Police Stress study. Chronobiol Int 2017;34:721-731.

20. Lee S, Chan LY, Chau AM, Kwok KP, Kleinman A. The experience of SARS- related stigma at Amoy Gardens. Soc Sci Med 2005;61:2038-2046.

21. Su T, Lien T, Yang C, et al. Prevalence of psychiatric morbidity and psychological adaptation of the nurses in a structured SARS caring unit during outbreak: a prospective and periodic assessment study in Taiwan. J Psychiatr Res 2007;41:119-130.

22. Ghalichi L, Pournik O, Ghaffari M, Vingard E. Sleep qualityamong health care workers. Arch Iran Med 2013;16:100-103

23. Li RH, Wing YK, Ho SC, Fong SY. Gender differences in insomnia-a study in the Hong Kong Chinese population. J Psychosom Res 2002;53:601-609.

24. Epidemiology Working Group for NCIP Epidemic Response, Chinese Center for Disease Control and Prevention. [The epidemiological characteristics of an outbreak of 2019 novel coronavirus diseases (COVID-19) in China] Zhonghua Liu Xing Bing Xue Za Zhi 2020;41:145-151.

25. The L. COVID-19: protecting health-care workers. Lancet 2020;395:922.

26. COVID-19: Spain reports 462 more deaths in one day. Anadolu Agency. Last Accessed Date: 23.03.2020. Available from: https://wwwaacomtr/en/ europe/covid-19-spain-reports-462-moredeaths- in-on day/1775994

27. Reeth OV, Weibel L, Spiegel K, et al. Interactions between stress and sleep: From basic research to clinical situations. Sleep Med Rev 2000;4:201-219.

28. Jarrin DC, Chen IY, Ivers H, Morin CM. The role of vulnerability in stress-re $\neg$ lated insomnia, social support and coping styles on incidence and persis $\neg$ tence of insomnia. J Sleep Res 2014;23:681-688.

29. Âkerstedt T. Psychosocial stress and impaired sleep. Scand J Work Environ
Health 2006;32:493-501.

30. Marjanovic Z, Greenglass ER, Coffey S. The relevance of psychosocial variables and working conditions in predicting nurses' coping strategies during the SARS crisis: an online questionnaire survey. Int J Nurs Stud 2007;44:991-998.

31. Johal SS. Psychosocial impacts of quarantine during disease outbreaks and interventions thatmay help to relieve strain. N Z Med J 2009;122:47-52.

32. Liu X, Kakade M, Fuller CJ et, al. Depression after exposure to stressful events: lessons learned from the severe acute respiratory syndrome epidemic. Compr Psychiatry 2012;53:15-23.

33. Chen CS, Wu HY, Yang P, Yen CF. Psychological distress of nurses in Taiwan who worked during the outbreak of SARS. Psychiatr Serv 2005;56:76-79.

34. Tam CWC, Pang EPF, Lam LCW, Chiu HFK. Severe acute respiratory syndrome (SARS) in Hong Kong in 2003: stress and psychological impact among frontline healthcare workers. Psychol Med 2004;34:1197-1204.

35. Chan AO, Huak CY. Psychological impact of the 2003 severe acute respiratory syndrome outbreak on health care workers in a medium size regional general hospital in Singapore. Occup Med (Lond) 2004;54:190196.

36. Maunder RG, Lancee WJ, Rourke S, et al. Factors associated with the psychological impact of severe acute respiratory syndrome on nurses and other hospital workers in Toronto. Psychosom Med 2004;66:938-942.

37. Suzuki K, Ohida T, Kaneita Y, Yokoyama E, Uchiyama M. Daytime sleepiness and sleep habits among hospital nurses. J Adv Nurs 2005;52:445453.

38. Xiang Y, Ma X, Cai Z, et al. The prevalence of insomnia, its sociodemographic and clinical correlates, and treatment in rural and urban regions of Beijing, China: a general population-based survey. Sleep 2008;31:1655-1662.

39. Chen R, Chou K, Huang Y, et al. Effects of a SARS prevention programme in Taiwan on nursing staff's anxiety, depression and sleep quality: a longitudinal survey. Int J Nurs Stud 2006;43:215-225.

40. Wu P, Fang Y, Guan Z, et al. The psychological impact of the SARS epidemic on hospital employees in China: exposure, risk perception, and altruistic acceptance of risk. Can J Psychiatry 2009;54:302-311.

41. Lange T, Dimitrov S, Born J. Effects of sleep and circadian rhythm on the human immune system. Ann NY Acad Sci 2010;1193:48-59. 